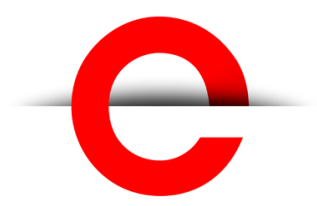

U T S

e PRES S
Gateways:

International Journal

of Community

Research and

Engagement

Vol. 12, No. 1

May 2019

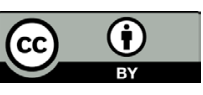

(c) 2019 by the author(s). This is an Open Access article distributed under the terms of the Creative Commons Attribution 4.0 International (CC BY 4.0) License (https:// creativecommons.org/licenses/ by/4.0/), allowing third parties to copy and redistribute the material in any medium or format and to remix, transform, and build upon the material for any purpose, even commercially, provided the original work is properly cited and states its license.

Citation: Adams, LB., Alter, TR., Parkes, MW., Reid, M., Woolnough, AP. 2019. Political economics, collective action and wicked socio-ecological problems: A practice story from the field. Gateways: International Journal of Community Research and Engagement, 12:1, Article ID 6342. https://doi.org/10.5130/ ijcre.v12i1.6496

ISSN 1836-3393 | Published by UTS EPRESS I UTS EPRESS | http://ijcre.epress.lib.uts. edu.au
SNAPSHOT ARTICLE (NON-REFEREED)

\section{Political economics, collective action and wicked socio-ecological problems: A practice story from the field}

\author{
Lisa B. Adams, ${ }^{1 *}$ Theodore R. Alter, ${ }^{2,3}$ Margot W. Parkes, ${ }^{4}$ Michael Reid, ${ }^{5}$ \\ Andrew P. Woolnough ${ }^{6,7}$ \\ ${ }^{1}$ Lisa Adams and Associates, Melbourne, Victoria 3000, Australia \\ ${ }^{2}$ Department of Agricultural Economics, Sociology, and Education, The Pennsylvania State \\ University, University Park, PA 16802, United States \\ ${ }^{3}$ Australian Center for Agriculture \& Law, University of New England, Armidale, NSW 2351, \\ Australia \\ ${ }^{4}$ School of Health Sciences, University of Northern British Columbia, Prince George, BC V2N \\ 4Z9, Canada \\ ${ }^{\mathbf{5}}$ Agriculture Victoria, Department of Jobs, Precincts and Regions, 1 McKoy Street, Wodonga, \\ Victoria 3690, Australia \\ 'Office of Victoria's Lead Scientist, Department of Jobs, Precincts and Regions, 121 Exhibition \\ Street, Melbourne, Victoria 3000, Australia \\ ${ }^{7}$ Ecology and Evolutionary Biology, School of Biological Sciences, The University of Adelaide, \\ Adelaide 5005, Australia
}

*Corresponding author: Lisa Adams; lb_adamsabigpond.net.au

DOI: https://doi.org/10.5130/ijcre.v12i1.6496

Article history: Received 06/03/2019; Revised 17/04/2019; Accepted 30/04/2019; Published 18/06/2019

\begin{abstract}
Empowering integrative, sustainable and equitable approaches to wicked socio-ecological problems requires multiple disciplines and ways of knowing. Following calls for greater attention to political economics in this transdisciplinary work, we offer a practitioner perspective on political economy and collective action and their influences on our community engagement practice and public policy. Our perspective is grounded in a pervasive wicked problem in Australia, invasive rabbits, and the emergence of the Victorian Rabbit Action Network. The network grew out of a publicly funded research project to support community-
\end{abstract}

1 financial support for the research, authorship, and/or publication of this article. 
U T S

e PRES S led action in rabbit management. Victorian residents and workers affected by rabbits - public and private land managers, scientists, government officers and others - were invited to engage in a participatory planning process to generate sustainable strategies to address the rabbit problem. Each stage in the process, which involved interviews, a workshop and consultations, was designed to nurture the critical enquiry, listening and learning skills of participants, advance understandings of the problem from multiple perspectives, generate collective options to guide decision-making, and encourage community-led collective action. We reflect on our understanding of these processes using the language and lens of political economics and, in particular, the context of democratic professionalism. In so doing, we define terms and refer to information resources that have enabled us to bring a practical working knowledge of political economics to our professional practice. Our intent is to motivate academics, community members, government officials and scientists alike to draw on their knowledge and field experiences and to share practice stories through the lens of political economics and collective action. This is an opportunity to engage each other in the small 'p' politics of how we understand and act on wicked problems, to negotiate and connect across disciplines, practical experiences and human difference, so that people may work more creatively and effectively together to address the challenging issues of our time.

\section{Keywords}

Community engagement, wicked problems, political economy, collective action, socioecological issues, practice story

\section{Introduction}

Empowering integrative, sustainable and equitable approaches to wicked socio-ecological problems is demanding work, requiring multiple disciplines and ways of knowing, and complex systems thinking (Brown, Harris \& Russell 2010; Schmid 2004; Waltner-Toews, Kay $\&$ Lister 2008). This article supports the call for greater attention to political economics in this transdisciplinary work (Bardosh 2016). A useful step in this direction is to cultivate a common language of political economics and foster conversation on its relevance to people's work on these problems. To this end, this article offers a practitioner story and perspective on the topic, grounded in a pervasive wicked problem in Australia: invasive rabbits.

The perspective draws on the specific example of the Victorian Rabbit Action Network (VRAN). The emergence of VRAN is described as a pretext to draw out insights on political economy, collective action and wicked problems, and as they relate to public policy.

\section{The Victorian Rabbit Action Network}

The European rabbit was introduced to Australia in the 1850s for hunting. This invasive species has since colonised the continent and the hearts and minds of its people (Box 1). Alongside these emotional attachments are ecological and economic impacts; rabbits threaten over 300 vulnerable native species (Department of the Environment 2016) and cost agribusinesses more than AUD200 million per year (Gong et al. 2009). These and other factors make rabbit management a pressing socio-ecological public policy issue in Australia. 
U T S

e PRES S
Box 1: Australia's conflicted socio-political history with the rabbit

When in 1859 Thomas Austin released wild rabbits on his Barwon Park estate to breed as game for shooting parties, it was in the commercial and cultural spirit of colonialism and the Acclimatisation Society of Victoria (ASV). Within a decade a rapidly growing wild rabbit population was raising alarm. The ASV folded, its policies discredited. By 1883 Australia's colonies had implemented rabbit destruction legislation and a rabbit export industry had been formed. While farmers and graziers wanted rabbit extermination, trappers and processors wanted ongoing trade, and trappers, seeking bargaining power with processors, unionised. Federation in 1901 coincided with droughts and large-scale environmental degradation, especially in arid lands. Whilst pastoralists blamed rabbits for the degradation, scientists like Francis Ratcliffe later argued it was overstocking of sheep. State-sponsored rabbit campaigns burgeoned, serving as an economic stimulus and bolstering much needed employment in rural communities, but the rabbit plagues continued. Community awareness of the environmental degradation caused by rabbits increased through the combined efforts of scientists, pastoralists, government officials and others. Introduction of the viral diseases myxomatosis in 1950 and rabbit haemorrhagic disease in 1995 resulted in enormous socio-ecological benefits. These benefits were curtailed, though, due to lack of follow-up coordinated effort using conventional controls and the co-evolution of virus virulence and rabbit disease resistance. Following the decline of one-on-one government agricultural extension services in the 1980s, new institutions emerged. The collective effort of community-led Landcare groups and regional catchment management authorities for instance now complement the work of individual land managers. Whilst the socio-political context has changed dramatically over time, the rabbits remain a costly, wicked socio-ecological problem.

(Sources: Coman 2010; Cooke 2014; Eather and Cottle 2015; Munday 2017; Watson 2014)

An ongoing challenge is to develop sustainable landscape-scale management strategies that have community support (Campbell 1997; Cooke 2012; Martin et al. 2016). In response, a publicly funded research project to support community-led action in rabbit management (the 'rabbit project') led to the creation of the Victorian Rabbit Action Network (Adams 2014).

The rabbit project applied a 'systems-strengthening, democratic, participatory approach' to developing rabbit management options for Victoria (Adams 2014). Underpinning the approach was the hypothesis that sustainable strategies are those created by the people most affected (Chambers \& Conway 1992; Kemmis \& McKinney 2011). Thus, Victorian residents and workers affected by rabbits - public and private land managers, scientists, government officers and others - were invited to engage in a participatory planning process, which included one-on-one interviews, a workshop and follow-up consultations. Each stage was designed to nurture critical enquiry and listening and learning skills of participants, advance understandings of the problem from a range of perspectives, acknowledge and engage difference and tension, generate collective options to guide future decision-making, and encourage community-led collective action (Curato, Niemeyer \& Dryzek 2013; Mathews 2014).

The process used to identify interviewees was purposive: care was taken to seek out diverse groups, interests and experiences. A first-person narrative of interview extracts informed a subsequent workshop with interviewees. The narratives helped participants identify their common passions and concerns, the sheer complexity of the problem, the location-specific 
U T S

e PRES S nature of solutions and the critical role of coordination in long-term landscape-scale change (Black 2008; Peters, Alter \& Shaffer 2010). Workshop participants then considered what types of interventions could help people to better plan, coordinate and evaluate their actions to manage rabbits. These ideas were further developed using complex systems and rich picture maps (Monk \& Howard 1998).

The overall process led to the creation of the Victorian Rabbit Action Network and an associated skills-based steering group (VRAN 2018a). The steering group worked with experts from the community, government and industry to implement a field-based training program in rabbit management. Program participants then elected to create their own learning network, which they named 'Leaps and Bounds'. Leaps and Bounds' members have since initiated networks and action plans in their own locales. In this way, VRAN is supporting a network of networks that connect local and expert knowledge and know-how to on-ground action. VRAN impacts and benefits can be understood through the ecological restoration example (Box 2), a series of video stories (VRAN 2018b), a formative evaluation (Furze 2016) and an impact analysis (Acil Allen Consulting 2017).

Box 2: How VRAN empowers collective action in Victoria's rangelands

The Mallee rangelands in northwest Victoria have been degraded by a 150 -year history of grazing pressure from livestock, rabbits and kangaroos (Sandell 2011). For over 25 years, land managers, government officials, scientists, pest contractors and others have worked together on a restoration ecology project to remediate the degradation. Ned's Corner Station, Victoria's largest, privately owned conservation property covers over 30000 hectares of the project area. The removal of rabbits from the station and direct seeding and planting of more than 60000 trees have led to the re-emergence of rare native plant species and grasses (Sandell 2011; VRAN 2018c). Through membership of Leaps and Bounds, the station manager has had access to the vast pool of knowledge, ideas, inspiration and support that comes from being connected to a wider community.

\section{Insights Regarding Political Economy and Collective Action}

We bring a practitioner perspective to understandings of political economy and its relevance to collective action on wicked socio-ecological problems. For us, political economics concerns human relationships and interdependence, and how formal rules (e.g. law and regulation) and informal rules (e.g. associated with cultural, organisational and behavioural norms) advantage some interests and disadvantage other interests. Our interest is to understand the impacts of these rules and how they manifest, and in turn the dynamics that lead to change in the rules themselves and change in the resultant distribution of impacts (Ostrom 1990; Schmid 2004; Waltner-Toews 2008). Selected terms are defined to aid understanding, provoke thinking and encourage others to share practice stories.

Before turning to the VRAN story, we note the role of rabbits as powerful agents in Australia's socio-political and economic history and how this has manifest over time (Box 1). This history highlights the importance of how formal and informal societal rules shape individual, group, organisation and community outcomes. During the early period of European settlement, dominant commercial and cultural interests drove how rabbits were 
seen and utilised. Later on, the power of the rabbit industry influenced economic policy affecting rabbits and their perceived utility. Ongoing alarm concerning the production losses and environmental degradation caused by rabbits shifted the science, policy and on-ground management focus towards biocontrol measures. These socio-political and economic forces have shaped perspectives on rabbits and rabbit management in Australia.

VRAN is the product of diverse actors who together identified rabbit management as a wicked problem requiring collective action (for further details, see Adams 2014). The defining feature of wicked problems is that people and groups understand and define these problems in different ways and as part of broader socio-ecological issues and concerns (Rittel \&Webber 1973). The problems and possible solutions are complex, uncertain, socially and politically contested, and change over time. We observed that the collective action to identify the features of the wicked rabbit management problem in Victoria motivated action, which gave effect to creative, new ways to connect knowledge and know-how to on-ground action. Systems thinking and acting beyond self-interest were evident.

Public policy responses to wicked problems involve authoritative, competitive and collaborative strategies. Power is dispersed differently among stakeholders under each strategy (APSC 2007). Power refers to having capacity to exercise an opportunity in your opportunity set, the ability to visit costs upon others, and the ability to have your interests count (Schmid 2004). Collaborative strategies, such as those used by the rabbit project and VRAN, place winwin at the core of problem solving and are favoured when sustainable individual and collective behaviour change is desired.

Politics and power relationships affect the policies and programs adopted and implemented under any type of strategy. These instruments in turn determine whose interests are best served. This distribution of advantages and disadvantages reflects the political economy of the rabbit problem. For instance, framing the rabbit problem as an agricultural economics issue at the national level may limit landscape scale change on private and public land due to economic and financial influences on mindsets and investment flows (Cooke 2012), particularly when a community may be motivated by conservation outcomes (e.g. Kearney et al.2018) rather than economics. VRAN empowers alternative narratives grounded in experience in a locale. These narratives, emphasising environmental quality, landholder collaboration and learning, and community-government shared responsibility, influence the rules and cultural expectations governing behaviour and what and who is advantaged or disadvantaged in the locale (Ostrom $2009,2010)$. In the rabbit project and VRAN, ecological restoration and strengthening citizen commitment and community partnerships, for example, can sit comfortably alongside agricultural economics as dominant narratives.

Politics is ubiquitous in the context of wicked problems requiring collective action. Small 'p' politics refers to citizen-centred democratic politics (Boyte 2004). Power plays are also ubiquitous because different interests naturally strive for advantage. Power play refers to behaviour or tactics intended to increase a person's or group's influence or power (Schmid 2004). Alongside a rich history of politics in rabbit management (Coman 2010; Munday 2017), power plays were evident in the rabbit project; for example, connected to a suggestion to promote a single graphic representation of the 'rabbit management system' in Victoria. This suggestion was at odds with the rich, complex picture maps generated by the workshop participants. This political tension was connected in part to a desire to offer a single lens for determining decisions and action at the state level, whereas from differing local perspectives the rabbit management system was not a singular, unified system. In effect, there were multiple

Gateways: International Journal of Community Research and Engagement, Vol. 12, No. 1, May 
U T S

e P R E S S

systems depending on whose perspectives, interests and narratives were being shared or considered.

Being mindful of these dynamics and drawing on principles of the politics of citizen engagement and associated empirical evidence (Campbell 1997; Chambers \& Conway 1992; Curato, Niemeyer \& Dryzek 2013; Kettering Foundation 2016; Ostrom 1990), the rabbit project assumed that an open invitation to participate would advance recognition of the need for collective action and tap into people's desire to effect change. It also assumed that widespread ownership of a collective action strategy would most likely arise when all parties with fundamental and differing interests in the problem participated in discussions about their differences and possible solutions. The rabbit project and VRAN embodied these politics of citizen engagement: citizens embracing small 'p' politics to understand a complex problem, apply critical thinking, negotiate difference, and reach collective agreement on future actions.

Responses to wicked problems require imagination and integration of many types of knowledge (Brown, Harris \& Russell 2010; Hallstrom, Guelstorf \& Parkes 2015). In practice, integration requires openness to learning from others as well as sharing of tasks and authority: a 'democratic professionalism' (Dzur 2008, 2017, 2019). The integration of local knowledge into socio-ecological strategies may challenge established hierarchies that prioritise government and formal scientific expertise (Boyte 2004; Fischer 2000). The rabbit project sought out local knowledge to ensure the creation of a joint solution, the Victorian Rabbit Action Network (Adams 2014). VRAN is thus grounded in the experience of people at the frontline of rabbit management, with scientific and government expertise regarded as 'on tap not on top' (Boyte 2016). This approach fosters respectful relationships, reciprocity, critical thinking, learning and accountability, and in ways that empower everyone involved (for empirical evidence we look to Brugnach et al. 2010; Curato, Niemeyer \& Dryzek 2013; Matthews 2014).

The rabbit project sought to create a safe space for people to realise the transformative potential of engaging difference, individual and social learning, collaboration and collective action. Gaventa (2006, p. 26) provides a useful analysis of power in participatory spaces: 'Power relations help to shape the boundaries of participatory spaces, what is possible within them, and who may enter'. The spaces are dynamic; change agents can build horizontal alliances that link strategies across spaces and vertical links between actions at different levels (Gaventa 2006; Parkes 2015). Transformation occurs when the power gained in one space (e.g. through new knowledge or skills) positively influences other spaces, and when change happens at both the grassroots and global levels. Transformation is evident in the new networks formed to create landscape-scale change.

Path dependence is present when the path of change is heavily influenced by past changes (Schmid 2004). Path dependence and habitual thinking are barriers to change, creativity and effective community-led action. They preference habit and history over the creative potential embedded in the dynamic web of interpersonal, socio-political and cultural relationships that underpin communities (Matthews 2014). Our experiences in the rabbit project suggest that participatory planning (co-creation) and policy development linked to social learning (learning as strategy) can address path dependence. For example, the Leaps and Bounds network originated from VRAN members. Leaps and Bounds' policies accommodate local visions, contexts, issues and insights, and mechanisms to integrate knowledge acquired through collective trial and error (Taleb 2012). On the one hand, community-led plans that evolve in response to on-the-ground learning may challenge government agencies with commandand-control mentalities and accountability systems that are distant from what success might 
look like in communities. On the other hand, policy-makers can take the wrong kinds of risks when they do not have to experience the setbacks of policy failure on wicked problems in communities. Taleb (2012) describes this potential inequity in terms of fairness in the dispersion of risk. An opportunity for future research on co-creation and learning as strategy is to uncover ways around these potential organisational challenges to create more effective responses to wicked problems (see Allen 2016; Hermans, Klerkx \& Roep 2015; Patrizi et al. 2013).

Narratives and stories help us frame what we see as possible. For instance, path dependent narratives limit our individual and collective ability to see new ways forward. Reframing the narrative, on the other hand, opens up new possibilities for change. Stories can also help people negotiate complexity, uncertainty, and moral and cultural differences (Black 2008; Brugnach et al. 2010; Howard et al. 2019). The rabbit project used narrative and rich picture maps to inform workshop discussion and expand individual and collective participant imagination and understandings of problems and solutions.

Collective action emerges over time and through dialogue as interest holders work together to navigate the power dynamics and everyday politics inherent in wicked problems. The work of the rabbit project, VRAN and Leaps and Bounds suggests that people's passions, desires, stories, concerns, experiences, commonalities and differences can be harnessed to generate creative solutions and action. The rabbit project experience validates our belief that people can indeed find ways to work better together (Brown \& Harris 2014; Mathews 2014; Ostrom 2009; Peters, Alter \& Shaffer 2010).

The formation, functioning and ongoing emergence of the rabbit project in Victoria and VRAN are grounded in a range of insights regarding political economy and collective action. While often overlooked, these insights can help transform current approaches to wicked socio-ecological problems.

For us, a central organising idea reflected in these insights is the notion of democratic professionalism. What distinguishes the democratic professionals in our schools, universities, hospitals, prisons, courts, government agencies and other traditional fields? They are the reform-minded innovators and collaborators who see citizens as having a stake in public decisions affecting individuals and groups; who share authority and knowledge; who act as enabling intermediaries between citizens and institutions; and who share experience, expertise and power in naming, framing and acting on important issues (Dzur 2008, 2017, 2019). Their slow-burn, load-bearing work, as described and evidenced by Dzur, shifts power balances mediated usually by tradition, funding agendas, technology and other means, thus changing social and organisational cultures to be more participatory and democratic. Democratic professionals' professional practices and personal lives respect and bring others into decisionmaking processes in democratic ways.

\section{An Invitation}

We invite others, academics, community members, government officials and scientists alike, to draw on their knowledge and field experiences and to share practice stories through the lens of political economics and collective action. As with the rabbit project, the opportunity is to engage each other in small 'p' politics of how we understand, address and act on wicked problems; to negotiate and connect across disciplines, practical experiences and difference, so that people may work more creatively and effectively together to address the challenging issues of our time. 
U T S

e PRES S

\section{Acknowledgements}

The authors acknowledge funding support from Agriculture Victoria, the former Invasive Animals Cooperative Research Centre (CRC) and the Australian Government through the CRC Program. This work was also supported by the USDA National Institute of Food and Federal Appropriations Project PEN04633, Accession number 1014522. We thank the many people who have contributed to the Victorian Rabbit Action Network and Siena Baker, Kylie Lingard and Tessa Sontheimer for their editorial assistance.

\section{References}

Acil Allen Consulting 2017, Victorian Rabbit Action Network impact analysis: Final report, viewed 23 February 2019, https://rabbitaction.com/wp-content/uploads/2018/08/VRAN-Impact-Analysis.pdf Adams, L 2014, Victorian Rabbit Management Collaboration Initiative, PestSmart Toolkit, publication, Invasive Animals Cooperative Research Centre, Canberra, ACT, viewed 23 February 2019, http://www. pestsmart.org.au/community-led-action-for-rabbit-management-in-victoria/

Allen, W 2016, Learning for sustainability web portal, viewed 23 February 2019, http:// learningforsustainability.net/

Australian Public Service Commission 2007, Tackling wicked problems: A public policy perspective, APSC, Canberra, ACT, viewed 23 February 2019, https://trove.nla.gov.au/version/44355556

Bardosh, K 2016, 'Unpacking the politics of zoonosis research and policy', in K Bardosh (ed.), One Health: Science, politics and zoonotic disease in Africa, Routledge, Abingdon, UK.

Black, L 2008, 'Deliberation, storytelling, and dialogic moments', Communication Theory, vol. 18, pp. 93-116, https://doi.org/10.1111/j.1468-2885.2007.00315.x

Boyte, H 2004, Everyday politics: Reconnecting citizens and public life, University of Pennsylvania Press, Philadelphia, PA.

Boyte, H 2016, 'Public universities and the future of democracy', Transcript of a speech delivered at Augsburg College, University of Illinois at Urbana-Champaign, 25 February 2016.

Brown, V \& Harris, J 2014, The human capacity for transformational change: Harnessing the collective mind, Routledge-Earthscan, London.

Brown, V, Harris, J \& Russell, J 2010, Tackling wicked problems through the transdisciplinary imagination, Earthscan, London.

Brugnach, M, Desulf, A, Henriksen, H \& van der Keur, P 2010, 'More is not always better: Coping with ambiguity in natural resource management', Journal of Environmental Management, vol. 92, pp. 78-84, https://doi.org/10.1016/j.jenvman.2010.08.029

Campbell, A 1997, Facilitating Landcare: Conceptual and practical dilemmas, in S Lockie \& F Vanclay (eds), Critical Landcare, Centre for Rural Social Research, Charles Stuart University, Wagga Wagga, NSW, pp. 143-52.

Chambers, R \& Conway, G 1992, Sustainable rural livelihoods: Practical concepts for the 21st century, IDS discussion paper 296, Institute of Development Studies, Brighton, UK.

Coman, B 2010, Tooth and nail: The story of the rabbit in Australia, Text Publishing, Melbourne, Victoria. 
Cooke, B 2012, Planning landscape-scale rabbit control, PestSmart Toolkit publication, Invasive Animals Cooperative Research Centre, Canberra, ACT, viewed 23 February 2019, http://www.pestsmart.org.au/ planning-landscape-scale-rabbit-control/

Cooke, B 2014, Australia's war against rabbits: The story of rabbit haemorrhagic disease, CSIRO Publishing, Collingwood, Victoria.

Curato, N, Niemeyer, S \& Dryzek, J 2013, 'Appreciative and contestatory inquiry in deliberative forums: Can group hugs be dangerous?', Critical Policy Studies, vol. 7, pp. 1-17, https://doi.org/10.1080/19460171 .2012 .758595

Department of the Environment 2016, Threat abatement plan for competition and land degradation by rabbits, Commonwealth of Australia, Canberra, viewed 23 February 2019, https://www.environment.gov. au/system/files/resources/bf9352c2-35ae-4a80-8828-96de630731a9/files/tap-rabbit-2016.pdf

Dzur, A 2008, Democratic professionalism: Citizen participation and the reconstruction of professional ethics, identity, and practice, The Pennsylvania State University Press, Pennsylvania, PA.

Dzur, A 2017, Rebuilding public institutions together: Professionals and citizens in a participatory democracy, Cornell University Press, New York.

Dzur, A 2019, Democracy inside: Participatory innovation in unlikely places, Oxford University Press, New York.

Eather, W \& Cottle, D 2015, 'The rabbit industry in south-east Australia, 1870-1970, in P Deery \&J Kimber (eds), Proceedings of the 14th Biennial Labour History Conference, Australian Society for the Study of Labour History, Melbourne, Victoria, viewed 27 March 2019, https://labourhistorymelbourne.files. wordpress.com/2015/02/the-rabbit-industry-in-south-east-australia-lh-proceedings1.pdf

Fischer, F 2000, Citizens, experts, and the environment: The politics of local knowledge, Duke University Press, Durham, North Carolina, NC.

Furze, B 2016, Formative evaluation summary: The Victorian Rabbit Action Network (VRAN). VRAN, Melbourne, VIC, viewed 23 February 2019, https://rabbitaction.com/wp-content/uploads/2015/04/ summary_vran-formative-evaluation_low-res.pdf

Gaventa, J 2006, 'Finding the spaces for change: A power analysis, IDS Bulletin, vol. 36, pp. 23-33, https://doi.org/10.1111/j.1759-5436.2006.tb00320.x

Gong, W, Sinden, J, Braysher, M \& Jones, R 2009, The economic impacts of vertebrate pests in Australia, Invasive Animals Cooperative Research Centre, Canberra, ACT, viewed 23 February 2019, https://www. pestsmart.org.au/the-economic-impacts-of-vertebrate-pests-in-australia/

Hallstrom, L, Guelstorf, N \& Parkes, M (eds) 2015, Ecosystems, society and health: Pathways through diversity, convergence and integration, McGill-Queens University Press, Montreal, Canada.

Hermans, F, Klerkx, L \& Roep, D 2015, 'Structural conditions for collaboration and learning in innovation networks: Using an innovation system performance lens to analyse agricultural knowledge systems', The Journal of Agricultural Education and Extension, vol. 21, pp. 35-54, https://doi.org/10.1080/1 389224X.2014.991113

Howard, T, Alter, T, Frumento, P \& Thompson, L 2019, Community pest management in practice: A narrative approach, Springer Nature, Singapore, https://doi.org/10.1007/978-981-13-2742-1 
U T S

e PRES S
Kearney, S, Cawardine, J, Reside, A, Fisher, D, Maron, M, Doherty, T, Legge, S, Silcock, J, Woinarski, J, Garnett, S, Wintle, B \&Watson, J 2018, 'The threats to Australia's imperilled species and implications for a national conservation response', Pacific Conservation Biology, https://doi.org/10.1071/PC18024

Kemmis, D \& McKinney, M 2011, 'Collaboration and the ecology of democracy', Sustainable Development Law \& Policy, vol. 12, no. 1, pp. 46-50, 69-70.

Kettering Foundation 2016, About, viewed 23 February 2019, http://www.kettering.org/about Martin, P, Low Choy, D, Le Gal, E, Lingard, K 2016, Discussion paper: Effective citizen action on invasive species, Invasive Animals Cooperative Research Centre, Canberra, ACT, viewed 23 February 2019, http:// www.pestsmart.org.au/wp-content/uploads/2016/05/DiscussionPaper_InstitutionalChallenge.pdf

Mathews, D 2014, The ecology of democracy: Ways to have a stronger hand in shaping our future, Kettering Foundation Press, Dayton, Ohio, OH, viewed 23 February 2019, https:/www.kettering.org/sites/default/ files/product-downloads/Ecology-Introduction.pdf

Monk, A \& Howard, S 1998, 'The rich picture: A tool for reasoning about work context, Interactions, vol. 5, pp. 12-30, viewed 23 February 2019, http://www.academia.edu/364777/Methods_and_Tools_the_ Rich_Picture_a_Tool_for_Reasoning_About_Work_Context?auto=download

Munday, B 2017, Those wild rabbits: How they shaped Australia, Wakefield Press, Adelaide, SA.

Ostrom, E 1990, Governing the commons: The evolution of institutions for collective action, Cambridge University Press, Cambridge, UK.

Ostrom, E 2009, 'Beyond markets and states: Polycentric governance of complex economic systems', American Economic Review, vol. 100, no. 3, pp. 641-72, https://doi.org/10.1257/aer.100.3.641

Ostrom, E 2010, 'A multi-scale approach to coping with climate change and other collective action problems', The Solutions Journal, vol. 1, no. 2, pp. 27-36, viewed 23 February 2019, http://www. thesolutionsjournal.com/article/a-multi-scale-approach-to-coping-with-climate-change-and-othercollective-action-problems/

Parkes, M 2015, “Just Add Water”: Dissolving barriers to collaboration and learning for health, ecosystems and equity', in L Hallstrom, N Guelstorf \& M Parkes (eds), Ecosystems, society and health: Pathways through diversity, convergence and integration, McGill-Queen's University Press, Montreal, Canada.

Patrizi, P, Thompson, E, Coffman, J \& Beer, T 2013, 'Eyes wide open: Learning as strategy under conditions of complexity and uncertainty', The Foundation Revierw, vol. 5, pp. 50-65, https://doi. org/10.4087/FOUNDATIONREVIEW-D-13-00012.1

Peters, S, Alter, T \& Shaffer, T 2010, 'Hot passion, cool judgement: Relating reason and emotion in democratic politics', Connections, pp. 15-18, The Kettering Foundation, Dayton, Ohio, OH, viewed 23 February 2019, http://www.kettering.org/catalog/product/connections-2010

Rittel, H \& Webber, M 1973, 'Dilemmas in a general theory of planning', Policy Sciences, vol. 4, pp. 155-69. https://doi.org/10.1007/BF01405730

Sandell, P 2011, Victoria's rangelands: In recovery or in transition? Parks Victoria, viewed 23 February 2019, http://www.parkweb.vic.gov.au/_data/assets/pdf_file/0020/521417/Rangeland-master_Final-c2. pdf

Schmid, A 2004, Conflict and cooperation: Institutional and behavioural economics, Blackwell Publishing Ltd, New Jersey, NJ. 
U T S

e P R E S S
Taleb, N 2012, Antifragile: Things that gain from disorder, Random House, New York.

Victorian Rabbit Action Network (VRAN) 2018a, About, VRAN, Melbourne, Victoria, viewed 23 February 2019, http://www.rabbitaction.com/about-vran/

Victorian Rabbit Action Network (VRAN) 2018b, Stories, Videos, VRAN, Melbourne, Victoria, viewed 23 February 2019, http://www.rabbitaction.com/stories/

Victorian Rabbit Action Network (VRAN) 2018c, A land manager's perspective on collaborative learning and rabbit action, video, VRAN, Melbourne, Victoria, viewed 23 February 2019, http://www.rabbitaction. com/stories/

Waltner-Toews, D, Kay, J \& Lister, N (eds) 2008, The ecosystem approach: Complexity, uncertainty, and managing for sustainability, Columbia University Press, New York.

Watson, D 2014, The bush: Travels in the heart of Australia, Penguin Group, Australia.
Gateways: International Journal of Community Research and Engagement, Vol. 12, No. 1, May 